\title{
THE NON-LINEAR RELATIONSHIP BETWEEN FISCAL DEFICITS AND INFLATION: EVIDENCE FROM AFRICA
}

Nurudeen Abu, Mohd Zaini Abd Karim

\begin{abstract}
Although, there is abundant research on the fiscal deficit-inflation relationship, little has been done to investigate the non-linear association between them, particularly in Africa. This study employs fixed-effects and GMM estimators to examine the non-linear relationship between deficits and inflation from 1999 to 2011 in 51 African economies, which are further grouped into high-inflation/low-income countries and moderateinflation/middle-income countries. The results indicate that the deficit-inflation relationship is non-linear for the whole sample and sub-groups. For the whole sample, a percentage point increase in deficit results in a 0.25 percentage point increase in inflation rate, while the relationship becomes quantitatively greater once deficits reach 23\% of GDP. The subsamples report different relationships. Although our results cannot be used as the base for generalization, we identify importance of grouping African countries according to their levels of inflation and/or income, rather than treating them as a homogeneous entity.
\end{abstract}

Keywords: Fiscal deficits, inflation, Africa

JEL: $H 30, H 60$

\section{INTRODUCTION}

One of the thorniest issues in economics discourse is whether fiscal deficits contribute to inflationary pressure in an economy. Although the seminal work of Sargent and Wallace (1981) triggered the debate on the relationship between deficits and inflation, researchers have attempted to examine the connection among budget deficits, monetary growth and inflation (see Hamburger and Zwick 1981; McMillin and Beard 1982; Ahking and Miller 1985). Catao and Terrrones (2005) suggested that if a government continuously runs budget deficits in order to attain macroeconomic objectives, it will resort to financing such deficits via credit creation and in turn puts upward pressure on inflation. The growth in money stock that results from the deficits raises private sector wealth and demand relative to the supply of goods and services, leading to higher inflation or prices. Moreover, the extent to which monetary policy is employed in balancing government's budget is the key to determining the impact of deficits on inflation (Sill 2005). The fiscal theory of price level (FTPL) on the other hand, states that

\footnotetext{
Nurudeen Abu, PhD

Othman Yeop Abdullah Graduate School of Business Univeristi Utara Malaysia

E-mail: abu.nurudeen@yahoo.com

\section{Mohd Zaini Abd Karim}

Professor

Othman Yeop Abdullah Graduate School of Business Univeristi Utara Malaysia

E-mail: zaini500@uum.edu.mv
} 
prices are not determined by monetary growth, but only adjust to the increase in the private sector nominal wealth caused by the deficits that are financed via bonds (Tekin-Koru and Özmen 2003).

The Ricardian Equivalence (RE) predicts that deficits may not lead to higher demand and prices since government tax cut in the current period would be financed by proportionate tax increases in the future. Thus, knowing that a higher tax would be imposed on them in the future to enable the government to repay its debt, consumers would not consider themselves wealthier and/or increase their demand to the extent that it would lead to inflation (Anoruo 2003). But in the absence of the RE, the increased wealth would lead to higher demand for goods and services and inflation (Tekin-Koru and Özmen 2003).

Earlier, Sutherland (1997) presented a model to explain how the level of public debt influences the impact of fiscal policy on consumption. The author argued that at moderate levels of debt fiscal policy has an expansionary effect, as current generations of consumers discount future taxes because they may be dead when a government debt stabilization program would be implemented. Given this, consumers will increase their demand, leading to inflation. However, at higher levels of debt current consumers know that there is a high probability that they would be alive when the fiscal stabilization programme comes into force. Therefore, deficits may have a dampening impact on consumers' demand and inflation.

It has also been suggested that in countries where the central bank is not independent, the government can easily influence monetary policy and compel the central bank to keep interest rates low so that the cost of borrowing and financing government's deficits will be less. This can result in inflation (Rother 2004). But in countries where the central bank is to some extent independent and freely pursues the objective of low and stable inflation, it is uncommon to see government running deficits to the level that it will ask the apex bank to print more money to enable it to finance its deficits (Sill 2005). In this case, deficits may not result in inflation. Even if a deficit is not monetized, it may still have an inflationary impact via reduced national savings, higher interest rates, lower private investment and declining output growth (Abu and Karim 2012). Also, many developing economies do not have a vibrant and well-developed capital market where government can raise funds through the issuance of debt instruments such as bonds and treasury bills. This gives government the leverage to always fall back and/or direct the central bank to create credit to enable it finance its deficits (Shahin 1992), with its attendant effects on prices. From the issues highlighted above, there appears to be controversy surrounding the exact relationship (and its direction) between deficits and inflation.

The role of fiscal policy on inflation has gained prominence in developing countries because they are perceived to be less efficient in tax collection, politically unstable and unable to access adequate external borrowing (Alesina and Drazen 1991; Cukierman, Edwards, and Tabellini 1992). These factors tend to reduce the relative cost of seigniorage, and they have increased their dependence on inflation tax (Jalil, Tariq, and Bibi 2014). Moreover, Jacobs, Schoeman, and Van Heerden (2002) contended that expansion in government deficits to a considerable extent is to blame for large debt, high inflation, inadequate investment and poor economic growth in developing countries. However, researchers have yet to give adequate attention to the issue of persistent and growing deficits in developing countries (Anoruo 2003).

A cursory look at available information (Figure 1) indicates that the group of countries considered in this study recorded deficits between 1999 and 2011, except in 2006 and 2008, when they had a surplus. In addition, the region's inflation rate remained relatively high, peaking at $139 \%$ in 2007 . Furthermore, the pattern of movement of deficits and inflation is not very clear, as they moved in the same direction in some years and opposite in others. For instance, while the average overall deficits (as a percentage of GDP) declined from $5.4 \%$ in 1999 to $3.6 \%$ in 2000 , the average inflation rate jumped from $17.2 \%$ to $24.0 \%$ during the same period. However, with a further increase in average overall deficits to $3.9 \%$, the average inflation rate dropped to $10.6 \%$ in 2002 . Although the average overall deficits declined to $0.7 \%$ in 2005 , the average inflation rate increased to $10.7 \%$. Interestingly, the overall surplus (as a percentage of GDP) in 2006 (3.6\%) and $2008(0.8 \%)$ coincided with high rates of inflation, average overall deficits increased gradually from $1.6 \%$ in 2009 to $3.3 \%$ in 2010 and $3.8 \%$ in 2011 , and the average inflation rate declined from $8.9 \%$ in 2009 to $6.0 \%$ in 2010, before climbing to $7.6 \%$ in 2011 .

Given the unclear pattern in movement of deficits and inflation, it is possible that the relationship between them is non-linear. Furthermore, since the average inflation rate is higher in low-income African countries relative to their middle-income counterparts (as we shall see later in the descriptive statistics in the discussion section) the effect of deficits on inflation may vary across different income groups (with different inflation levels). It has been suggested that the deficits-inflation association may vary across countries with different levels of inflation (Catao and Terrones 2005). 
Figure 1: Movements in inflation rate and budget deficits in selected African countries

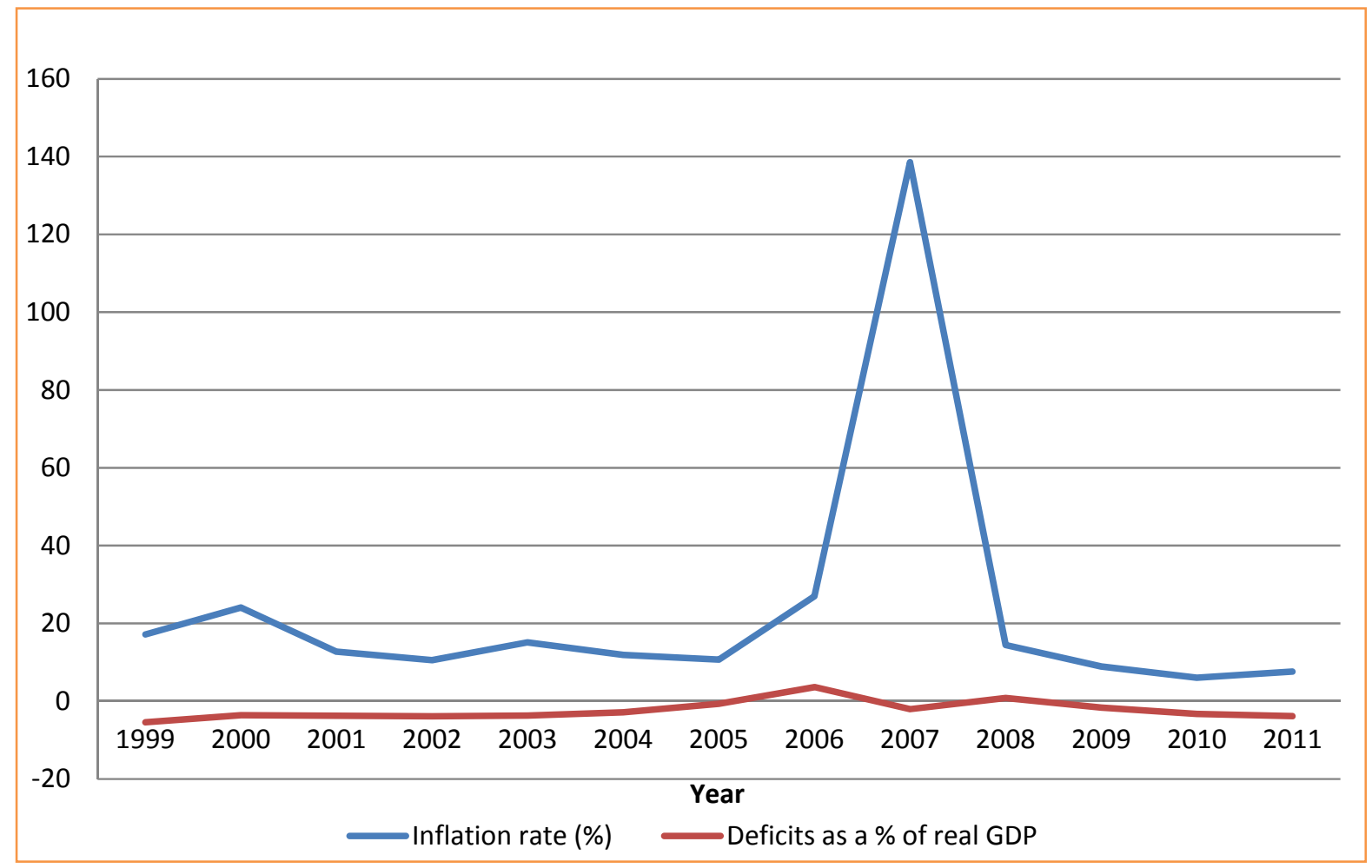

Source: Authors computation base on data obtained from the African Development Bank statistics pocketbook (various issues).

The question that arises from our discussion is whether the deficits-inflation relationship is non-linear in African countries, and if the effect of deficits on inflation varies across different income groups (with varying inflation rates). Thus, the main objective of this study is to examine whether the relationship between deficits and inflation is non-linear, including investigating if the effect of deficits on inflation varies across different income groups in Africa.

The present study is relevant because Asiedu (2006) suggested that studies focusing on Africa are important due to the general belief that the Africa is structurally different from other regions of the world, that the lessons from East Asia or Latin America are not applicable to the region because their situations are fundamentally different, and that Africa's leaders can learn from one another. Moreover, empirical studies that pay attention to Africa's performance will have greater acceptability among the continent's policymakers (Asiedu 2006). Following the introduction, the second section reviews the relevant literature on deficits and inflation, while the third section contains a description of the study's methods and data analysis. Section four includes the study's results and their discussion, while the fifth section provides recommendations and conclusions.

\section{REVIEW OF RELEVANT LITERATURE}

Many studies have been conducted to examine the relationship between deficits and inflation, both in developing and developed countries. Whereas some studies discovered that rising fiscal deficits lead to higher inflation in developing and high-inflation countries, others found an insignificant impact from deficits on inflation in advanced and low-inflation economies. For instance, Jalil, Tariq, and Bibi (2014) tested the FTPL for Pakistan from 1972 to 2012, using the autoregressive distributed lag (ARDL) model. The empirical evidence illustrates that deficits have a positive impact on inflation. Other variables that have a positive effect on inflation include interest rates, government sector borrowing and private borrowing. Habibullah, Cheah, and Baharom (2011) employed the granger causality test within the error correction framework to examine the long-run relationship between deficits and inflation in 13 Asian countries. The authors confirmed the existence of a long-run relationship between the variables, and concluded that deficits contribute to inflation in developing countries in Asia. Lin and Chu (2013) employed a dynamic panel quantile regression model under an ARDL specification to examine the deficit-inflation relationship in 91 countries during the period of 1960-2006. The results 
demonstrate that fiscal deficit has a strong effect on inflation in high-inflation episodes, but the effect of deficits on inflation is weak in low-inflation episodes. Similarly, Catao and Terrones (2005) used dynamic panel techniques to examine both the short-run and long-run effects of fiscal deficits on inflation in 107 countries from 1960 to 2001. The empirical evidence indicates the existence of a strong and positive relationship between deficits and inflation in high-inflation and developing countries.

In addition, Edwards and Tabellini (1991) reported that deficits do have a positive effect on inflation for a sample of developing countries. Moreover, Fischer, Sahay, and Vegh (2002) found a strong relationship between deficits and high inflation for some countries in the sample of 133 countries they considered in their study. Sahan and Bektasoglu (2010) studied the relationship between deficits and inflation in Turkey and 16 European Union countries using cointegration tests by Pedroni $(1995,1999)$ and Larsson, Lyhagen and Löthgren (2001). The results indicate that the existence of a long-run association between deficits and inflation in certain EU countries including the Czech Republic, Hungary, Slovakia, Sweden and Turkey. Metin (1998) analyzed the empirical relationship between inflation and budget deficits in Turkey within a multivariate cointegration framework. The results demonstrate that budget deficits had an inflationary impact on the Turkish economy. Tan (2006) investigated the short-run and long-run relationship between deficits, inflation and economic growth in Malaysia from 1966 to 2003. The author's findings indicate that deficits had a short-run inflationary effect on the economy because they were being monetized. Solomon and de Wet (2004) employed cointegration analysis to examine the relationship between budget deficits and inflation in Tanzania over the period 19672001. The authors confirmed a causal relationship running from budget deficits to inflation due to monetization of the deficits.

On the other hand, some studies have established that deficits do not have inflationary effect in developed and low-inflation economies. Marco and Butters (2010) illustrated that large deficits neither coincided with high inflation nor preceded inflation in Finland, Japan, and Sweden, and attributed it to the independence/autonomy enjoyed by central banks in the countries. Sahan and Bektasoglu (2010) also found the absence of any relationship between deficits and inflation in EU countries including Austria, Belgium, Denmark, France, Germany, Italy, the Netherlands, Norway, Spain and the U.K. Similarly, Catao and Terrones (2005) failed to establish a significant relationship between deficits and inflation in low-inflation advanced economies. Fischer, Sahay, and Vegh (2002) suggested that there is no clear association between deficits and inflation in low-inflation countries. Perkarski (2008) concluded that worsening public finance or rising deficits may not account for the rising inflation in high-inflation economies. King and Plosser (1985) studied the relationships among fiscal deficits, money growth and inflation in the United States and 12 other countries. The authors asserted that deficits do not lead to money growth and inflation.

De Han and Zelhorst (1990) used nonparametric correlation measures to study the relationship between seigniorage and government deficits in 17 developing countries that were further categorized into low-inflation and high-inflation groups. The authors discovered a weak association between seigniorage and government deficits, but the relationship is stronger during high-inflation episodes. Karras (1994) examined the effects of budget deficits (along with money growth, investment and real output growth) on inflation in a sample of 32 countries. He concluded that deficits do not lead to high inflation because they are not monetized. Other studies have confirmed a strong link between deficits and inflation in economies where the securities or capital market is less developed (see Cottarelli, Griffiths, and Moghadam 1988).

Despite the numerous studies on the deficits-inflation relationship, little has been done to examine if the relationship is non-linear particularly in the developing region of Africa. Given that the movement in deficits and inflation is not clear (as we pointed out in the introduction) it is possible that the relationship between them is non-linear, and any estimated relationship between them may vary. This study extends the literature by examining whether the deficits-inflation relationship is non-linear in African countries.

\section{METHOD AND DATA ANALYSIS}

This study employs a panel dataset to investigate the relationship between fiscal deficits and inflation in 51 African countries from 1999 to 2011. In deriving the inflation model, we employed the ideas of the FTPL which postulates that deficits leads to inflation and the monetarists' assertion that it is the growth in the money supply that results in inflation. For instance, the FTPL argues that if a government persistently runs deficits, it has to finance it through credit creation (Catao and Terrones 2005). The accompanying credit expansion raises aggregate demand. Given that supply often lag behind demand, this will results in higher prices. 
In addition, poor fiscal policy makes it easy for governments to shorten the maturity structure of their debt including rolling over the debt frequently (Amato and Gerlach 2002). This increases the risk of an impending confidence crisis that would requires the central bank to step in to monetize a portion of or the total debt, leading to higher inflation. Similarly, deficits raises inflation rate via a crowd-out effect (Fischer 1993). Rising deficits leads to declining aggregate savings, putting upward pressure on rates of interest and lowering private investment and production. The low level of output results in a scarcity of goods and services and higher inflation.

The Quantity Theory of Money, on the other hand, argues that growth in money stock leads to high inflation. This notion is based on the money neutrality assumption that money does not have a significant effect on real variables such as output. Therefore, any growth in monetary aggregates will only raise demand relative to supply, leading to higher prices. Even though the classical school argues that monetary growth is the major cause of inflation, they submit that deficits can lead to inflation if deficits are monetized (Hamburger and Zwick 1981). The foregoing discussion suggests that inflation is the outcome of both monetary and fiscal policies.

Thus, we specify a model in which inflation (INF) is dependent on deficits (DEF) and money supply growth (MOS) as follows.

$$
I N F_{i t}=\alpha_{10}+\alpha_{11} D E F_{i t}+\alpha_{12} M O S_{i t}+U_{1 i t}
$$

Furthermore, since deficit financing is often more than not intended to enhance a country's productive capacity via investment in socio-economic infrastructures, among other things, output growth is therefore expected to accompany fiscal expansion. The growth in output in turn may have some impact on the level of inflation. For instance, as an economy experiences output expansion, the demand for factor inputs will increase. Consequently, this leads to the exhaustion and scarcity of inputs and as a result increases in their prices. On the other hand, sustained output growth will result in supply matching the demand, which might have arisen from the increased deficits, thus putting inflation under control. Based on these arguments, we include economic growth (RGDP) as a potential determinant of inflation in our model. The new inflation model is:

$$
\begin{aligned}
I N F_{i t}= & \alpha_{20}+\alpha_{21} D E F_{i t}+\alpha_{22} M O S_{i t} \\
& +\alpha_{23} R G D P_{i t}+U_{2 i t}
\end{aligned}
$$

As we stated in the introductory section, the movement in deficits and inflation suggests that their relationship may be non-linear and vary over time. Therefore, an attempt would be made to ascertain whether non-linearity holds for the variables. In fact, Catao and Terrones (2005) argued that there is need for an econometric model that captures the non-linearity between deficits and inflation. To this end, we introduce a deficits-square variable or quadratic term (DEF*DEF) in the model to capture the non-linearity between deficits and inflation. Thus, we have a model of the following form:

$$
\begin{gathered}
I N F_{i t}=\alpha_{30}+\alpha_{31} D E F_{i t}+\alpha_{32} D E F_{i t} * D E F_{i t} \\
+\alpha_{33} M O S_{i t}+\alpha_{34} R G D P_{i t}+U_{3 i t}
\end{gathered}
$$

Where it refers to time period $t$ in country $i$. The variables are measured or defined as follows. RGDP is the growth rate of real gross domestic product and MOS is broad money supply (M2) growth. INF is inflation rate, while DEF is budget deficits as a percentage of GDP. The data were collected from the African Development Bank statistics pocketbook (various issues), and cover the 1999-2011 period for 51 African countries (excluding Liberia, Somalia and South Sudan which were left out due to the unavailability of data).

In order to estimate the deficits-inflation relationship, we employed a fixed-effects estimator that allows for unobserved time-invariant variation in country specific characteristics, with robust standard errors. In addition, since our panel of countries has data for a short time span (that is, a short time series and relatively large cross section), we also employed the Generalized Method of Moments (GMM) estimator (Arellano and Bond 1991). The GMM (dynamic) model allows us to take into consideration the fact that inflation rate, fiscal deficits and other regressors are correlated with time-invariant country specific characteristics. Moreover, the introduction of an inflation rate variable lagged by one period allows for the persistence of inflation rate.

The GMM estimator uses the first differences of both dependent and explanatory variables. Despite its advantages over the fixed-effects estimator, the GMM estimator has some shortcomings. Even though the first differencing eliminates country specific effects, the lagged dependent variable is correlated with the disturbance term so that further lags of the dependent variable including the first differences of the independent variables are employed as instruments. In this case, using the one-step GMM estimator with robust standard error will result in inefficient estimates (that is, large standard errors). This necessitates the 
employment of the two-step GMM estimator which is more efficient compared with the one-step GMM estimator.

In order to check for the robustness of the GMM estimator, we perform two main tests. The first test is the Hansen test of over-identification. This tests the validity of the instruments employed, including validating the results. The second test tests the presence of serial correlation. The autoregressive tests give useful information on whether the disturbance terms in the first difference regression display serial correlation. While we expect the disturbance term in first difference to have first-order serial correlation, the existence of second-order serial correlation renders the GMM estimates inconsistent. In essence, the absence of secondorder serial correlation validates the model.

\section{RESULTS AND DISCUSSION}

Prior to estimating the inflation model, we computed the descriptive statistics for the variables employed in this study. Recall that the objective of this study is to examine whether the relationship between deficits and inflation is non-linear, in addition to investigating if the effect of deficits on inflation varies across different income groups (with varying inflation levels). Therefore, we grouped the 51 countries in our sample according to their level of income. Based on the World
Bank grouping, our sample is divided into low-income countries and middle-income countries. The low income countries sub-group comprises of 24 countries, while the middle income countries sub-group consists of 27 countries. The descriptive statistics in Table 1 indicates that the mean (average) inflation rate for the whole sample is $23.59 \%$. Interestingly, the average inflation rate for the middle-income countries sub-group is $9.11 \%$ compared to $39.84 \%$ for the lowincome countries sub-group.

These suggest that low-income African countries are also high-inflation countries, and middle-income countries are moderate-inflation countries. Thus, one may expect the deficits-inflation relationship to vary overtime across different income groups with different inflation levels.

Next, we proceed with our analysis by estimating the inflation model using a fixed-effects estimator. The results in Table 2 demonstrate that money supply growth has a positive and significant effect on inflation ( $\rho$-value $=0.0000)$, but economic growth has a significant and negative effect on inflation ( $\rho$-value $=0.0004$ ). However, deficits and deficits-square do not have any significant effect on inflation. This may be due to the fact that the fixed-effects estimator fails to take into account the dynamics of inflation behavior.

The results of GMM estimation for the model that exclude deficits-square are reported in Table 3. In interpreting the GMM estimates, we focus on models

Table 1: Descriptive statistics

\begin{tabular}{|c|c|c|c|c|c|}
\hline \multicolumn{6}{|c|}{ Whole sample } \\
\hline & Mean & Max & Min & Std. Dev. & Obs. \\
\hline INF & 23.59 & 6723.70 & -8.70 & 267.66 & 656 \\
\hline DEF & -2.33 & 51.40 & -124.90 & 10.18 & 663 \\
\hline RGDP & 4.54 & 48.10 & -41.80 & 5.95 & 661 \\
\hline MOS & 32.53 & 6194.40 & -77.50 & 260.68 & 606 \\
\hline \multicolumn{6}{|c|}{ Middle-income countries } \\
\hline & Mean & Max & Min & Std. Dev. & Obs. \\
\hline INF & 9.11 & 325.00 & -8.50 & 24.63 & 347 \\
\hline DEF & -0.71 & 51.40 & -124.9 & 11.66 & 351 \\
\hline RGDP & 4.42 & 48.10 & -41.80 & 5.63 & 349 \\
\hline MOS & 18.77 & 530.9 & -26.30 & 37.52 & 327 \\
\hline \multicolumn{6}{|c|}{ Low-income countries } \\
\hline & Mean & Max & Min & Std. Dev. & Obs. \\
\hline INF & 39.84 & 6723.70 & -8.70 & 388.80 & 309 \\
\hline DEF & -4.15 & 41.60 & -54.50 & 7.83 & 312 \\
\hline RGDP & 4.67 & 43.40 & -14.10 & 6.28 & 312 \\
\hline MOS & 48.66 & 6194.40 & -77.50 & 381.77 & 279 \\
\hline
\end{tabular}

Source: Authors computations based on data collected from the African Development Bank Statistics Pocketbook (various issues). +/- DEF implies budget surplus/budget deficits. 
Table 2: Fixed effects estimates for whole sample (Dependent variable: INF)

\begin{tabular}{|c|c|c|}
\hline Regressor & 2(a) & 2(b) \\
\hline Constant & $-8.5069(2.5231)[0.0008]$ & $-8.4896(2.5189)[0.0008]$ \\
\hline DEF & $0.0529(0.1692)[0.7544]$ & $0.0785(0.1897)[0.6792]$ \\
\hline$D E F * D E F$ & & $0.0007(0.0016)[0.6871]$ \\
\hline RGDP & $-0.7010(0.1952)[0.0004]$ & $-0.7077(0.1967)[0.0004]$ \\
\hline MOS & $1.0635(0.0334)[0.0000]$ & $1.0635(0.0334)[0.0000]$ \\
\hline R2 & 0.9835 & 0.9835 \\
\hline No of Obs. & \multicolumn{2}{|c|}{599} \\
\hline No of Countries & \multicolumn{2}{|c|}{51} \\
\hline
\end{tabular}

Robust standard errors generated using the panel corrected standard error (PCSE) method are in brackets. Probability values are in square brackets.

that are valid and have consistent estimates (using the autoregressive test for the presence of secondorder serial correlation and the J-statistic test for the validity of instruments). The results illustrate that there is an absence of second-order serial correlation $(\rho$-value $=0.1780$ ), while the $J$-statistic indicates that the instruments are valid ( $\rho$-value $=0.4733$ ) in the two-step GMM estimates. The results also reveal that money supply growth has a significant and positive effect on inflation ( $\rho$-value $=0.0000$ ), while economic growth has a significant and negative effect on inflation ( $\rho$-value $=0.0000$ ).

We continued our analysis by including the deficits-square in the model. The results reported in Table 4 demonstrate that the two-step GMM estimator is more efficient because the autoregressive test reveals that there is an absence of second-order serial correlation in the estimates ( $\rho$-value $=0.2110)$, and the J-statistic shows that the instruments are valid ( $\rho$-value $=0.5168)$. In addition, the results indicate that the deficits-inflation relationship is non-linear, and that the non-linear term is statistically significant $(\rho$-value $=0.0000)$.

It must be pointed out that it is difficult to interpret the coefficient of squared independent variables as in the case of DEF*DEF. However, one can calculate the breaking point by differentiating the estimates with respect to DEF. This helps us to get an idea of the deficits value where the relationship changes (this is the turning or breaking point of the curve). For instance, taking the derivative of the estimates in Table 4 with respect to DEF yield $0.2404+0.0052^{*}(2)=0.25$. Next, we take the ratio of the coefficient of the linear term (DEF) to twice the coefficient of the non-linear or quadratic term (DEF*DEF) to enable us interpret the relationship correctly. Thus, 23.12 [or $0.2404 / 2(0.0052)$ ] is the threshold or value of deficits share in GDP at which the relationship changes or reverses.

Overall, the relationship is positive as a percentage point increase in DEF ( $\%$ of GDP), ceteris paribus and on average, results in a 0.25 percentage points rise in the rate of inflation in African countries over the

Table 3: GMM estimates for whole sample without deficits-square (Dependent variable: INF)

\begin{tabular}{|c|c|c|}
\hline Regressor & One-step & Two-step \\
\hline INF(-1) & $0.9048(0.4113)[0.0283]$ & $0.9052(0.0008)[0.0000]$ \\
\hline DEF & $0.0182(0.3767)[0.9614]$ & $0.0069(0.0098)[0.4793]$ \\
\hline RGDP & $-1.1982(0.7283)[0.1006]$ & $-1.1922(0.0079)[0.0000]$ \\
\hline MOS & $0.9778(0.0538)[0.0000]$ & $0.9777(0.0001)[0.0000]$ \\
\hline \multicolumn{3}{|l|}{ No of obs. } \\
\hline No of Countries & & \\
\hline Diagnostics: & & \\
\hline J-statistic & $223.45[0.0000]$ & $46.98[0.4733]$ \\
\hline$A R(2)$ & $2.30[0.0212]$ & $1.32[0.1780]$ \\
\hline
\end{tabular}

Heteroskedasticity-robust standard errors are in brackets. Probability values are in square brackets. AR(2) is a test of secondorder serial correlation. J-test is the Hansen over-identification test. 
Table 4: GMM estimates for whole sample with deficits-square (Dependent variable: INF)

\begin{tabular}{|c|c|c|}
\hline Regressor & One-step & Two-step \\
\hline INF(-1) & $0.9090(0.0006)[0.0263]$ & $0.9096(0.0006)[0.0000]$ \\
\hline DEF & $0.2509(0.0119)[0.7287]$ & $0.2404(0.0119)[0.0000]$ \\
\hline$D E F * D E F$ & $0.0057(0.0005)[0.0000]$ & $0.0052(0.0005)[0.0000]$ \\
\hline RGDP & $-1.2824(0.0102)[0.0800]$ & $-1.2795(0.0102)[0.0000]$ \\
\hline MOS & $0.9773(0.0001)[0.0000]$ & $0.9773(0.0001)[0.0000]$ \\
\hline No of obs. & \multicolumn{2}{|c|}{491} \\
\hline No of Countries & \multicolumn{2}{|c|}{51} \\
\hline \multicolumn{3}{|l|}{ Diagnostics: } \\
\hline J-statistic & $214.65[0.0000]$ & $44.93[0.5168]$ \\
\hline $\mathrm{AR}(2)$ & $2.18[0.0290]$ & $1.25[0.2110]$ \\
\hline
\end{tabular}

Heteroskedasticity-robust standard errors are in brackets. Probability values are in square brackets. AR(2) is a test of secondorder serial correlation. J-test is the Hansen over-identification test.

observed period. A positive coefficient on DEF*DEF indicates a concave upward relationship (more specifically, a right-side-up parabola). In other words, the relationship between fiscal deficits and inflation is positive and becomes quantitatively larger once fiscal deficits reach $23.12 \%$ of GDP (i.e., excessive government spending fuels inflation). Furthermore, the results indicate that money supply growth has a positive and significant effect on inflation ( $\rho$-value $=0.0000$ ), but economic growth has a negative and significant effect on inflation ( $\rho$-value $=0.0000$ ).

Moreover, we examined whether the deficitsinflation relationship varies across different income groups (with varying inflation levels). We wish to state that (henceforth) only results of estimations for models consisting of deficits-square are reported because it is in these models we found deficits and/or deficits-square to be significant. Furthermore, since deficits and/or deficits-square are insignificant in the fixed-effects estimations, only the results of the GMM estimation are reported.

The results of the GMM estimation for high-inflation/low-income countries presented in Table 5 illustrate that the two-step GMM estimator is more efficient, as an autoregressive test indicates the absence of second-order serial correlation in the estimates ( $\rho$-value $=0.3228)$, while the $J$-statistic reveals that the instruments used are valid ( $\rho$-value $=0.6231$ ). The results of the two-step GMM estimation demonstrate that the deficits-inflation relationship is non-linear for high-inflation/low-income countries, and the quadratic term is significant ( $\rho$-value $=0.0000$ ). Taking the first derivative of the estimates with respect to DEF yields $-1.2597+0.0269 *(2)=-1.21$. The ratio of the coefficient of the linear term (DEF) to twice the coefficient of the quadratic term (DEF*DEF) is -23.41 [or $-1.2597 / 2(0.0269)]$.

Overall, the relationship is negative as a percentage

Table 5: GMM estimates for low income countries (Dependent variable: INF)

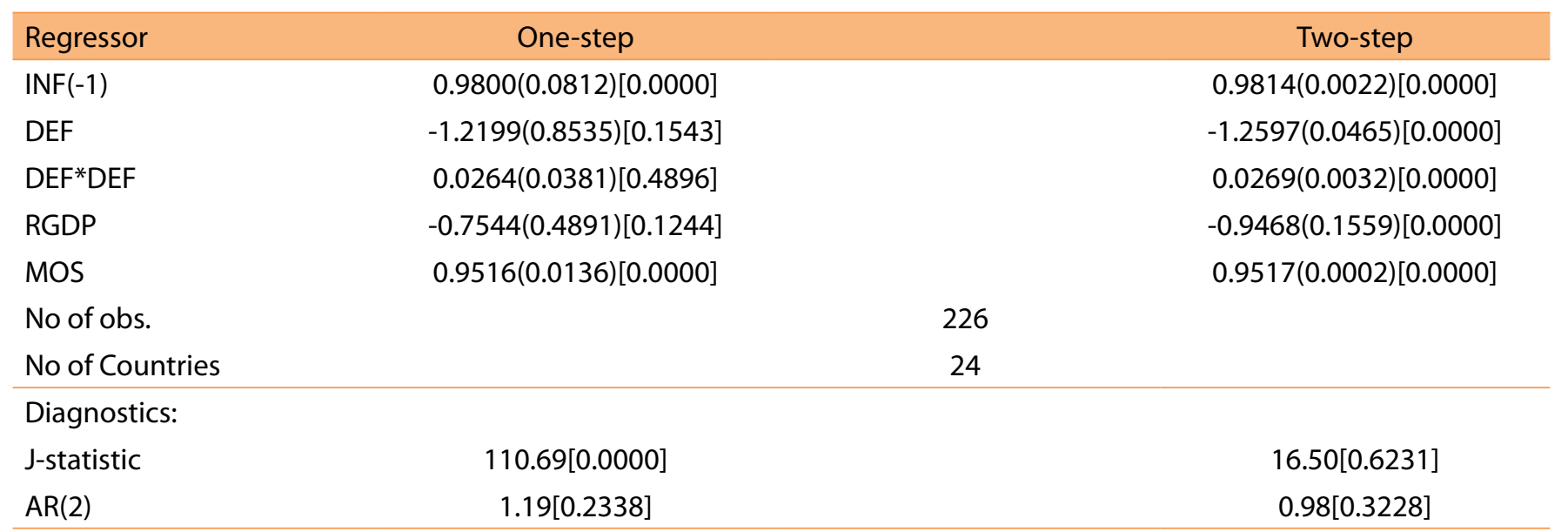

Heteroskedasticity-robust standard errors are in brackets. Probability values are in square brackets. AR(2) is a test of secondorder serial correlation. J-test is the Hansen over-identification test. 
Table 6: GMM estimates for middle income countries (Dependent variable: INF)

\begin{tabular}{|c|c|c|}
\hline Regressor & One-step & Two-step \\
\hline INF(-1) & $0.2294(0.1136)[0.0445]$ & $0.2282(0.0015)[0.0000]$ \\
\hline DEF & $-0.1832(0.1997)[0.3597]$ & $-0.1855(0.0053)[0.0000]$ \\
\hline $\mathrm{DEF}^{*} \mathrm{DEF}$ & $-0.0016(0.0018)[0.3666]$ & $-0.0017(0.0001)[0.0000]$ \\
\hline RGDP & $-0.7944(0.4012)[0.0488]$ & $-0.8022(0.0120)[0.0000]$ \\
\hline MOS & $0.7079(0.1603)[0.0000]$ & $0.7072(0.0013)[0.0000]$ \\
\hline No of obs. & \multicolumn{2}{|c|}{265} \\
\hline No of Countries & \multicolumn{2}{|c|}{27} \\
\hline \multicolumn{3}{|l|}{ Diagnostics: } \\
\hline J-statistic & $106.10[0.0003]$ & $24.04[0.3451]$ \\
\hline $\mathrm{AR}(2)$ & $-0.20[0.8343]$ & $0.24[0.8080]$ \\
\hline
\end{tabular}

Heteroskedasticity-robust standard errors are in brackets. Probability values are in square brackets. AR(2) is a test of secondorder serial correlation. J-test is the Hansen over-identification test.

point increase in DEF (\% of GDP), ceteris paribus and on average, results in a 1.21 percentage points fall in the rate of inflation. A positive coefficient on $D E F{ }^{*} D E F$ indicates a concave upward relationship. In other words, the relationship between fiscal deficits and inflation in low-income and high-inflation African countries is negative overall, but less so once the fiscal deficits reach $23.41 \%$ of GDP. Also, the results illustrate that money supply growth has a positive and significant effect on inflation ( $\rho$-value $=0.0000$ ), but economic growth has a significant and negative effect on inflation ( $\rho$-value $=0.0000$ ).

In addition, the results of the GMM estimation for moderate-inflation/middle-income countries reported in Table 6 reveal that the two-step GMM estimator is more efficient, because the autoregressive test illustrates that there is an absence of second-order serial correlation in the estimates (at a $\rho$-value $=0.8080$ ), while the J-statistic indicates that the instruments are valid ( $\rho$-value $=0.3451)$. The results also reveal that the deficits-inflation relationship is non-linear, and the coefficient of the non-linear term is statistically significant ( $\rho$-value $=0.0000)$. The first derivative of the estimates with respect to DEF is $-0.1855-0.0017^{*}(2)=-0.19$. The ratio of the coefficient of the linear term (DEF) to twice the coefficient of the non-linear term (DEF* DEF) is 54.56 [or $-0.1855 / 2(-0.0017)]$. Overall, the relationship is negative, as a percentage point increase in DEF (\% of GDP), ceteris paribus and on average, results in a 0.19 percentage points fall in the rate of inflation. $A$ negative coefficient on DEF*DEF indicates a concave downward relationship. In other words, the relationship between fiscal deficits and inflation is negative overall, but more so for fiscal deficits below $54.56 \%$ of GDP. Also, the results demonstrate that money supply growth has a positive and significant effect on inflation
( $\rho$-value $=0.0000)$, and economic growth has a significant and negative effect on inflation ( $\rho$-value $=0.0000$ ).

The results reported above are indeed revealing. The fixed-effects estimates show that deficits and deficits-square do not have any significant effect on inflation. This may be due to the fact that the fixed-effects model does not take into account the dynamics of inflation behavior. In addition, the diagnostic tests demonstrate that the two-step GMM estimator is more efficient because the autoregressive tests indicate that there is no presence of second-order serial correlation in the estimates. Moreover, the J-statistic validates the model, as it suggests that the instruments employed are valid.

The results also illustrate that the deficits-inflation relationship is non-linear for the whole sample, including moderate-inflation/middle-income countries and high-inflation/low-income countries. For the whole sample, a percentage point increase in deficits results in 0.25 percentage points increase in inflation rate. The relationship becomes quantitatively greater once fiscal deficits reach $23.12 \%$ of GDP. In the case of high-inflation/low-income countries, a percentage point increase in fiscal deficits leads to a 1.21 percentage points fall in inflation rate. The relationship gets quantitatively lesser once fiscal deficits reach $23.41 \%$ of GDP. In moderate-inflation/middle-income countries, a percentage point increase in fiscal deficits results in a 0.19 percentage points fall in inflation rate. The relationship becomes quantitatively greater for fiscal deficits below $54.56 \%$ of GDP.

These findings are not surprising, as it was pointed out earlier that the movement in deficits and inflation is not very clear, and suggested that the relationship between them may be non-linear. Moreover, the results reveal that the effect of deficits on inflation is 
different for countries at different level of income and varying inflation levels. Catao and Terrones (2005) had earlier reported different effects from deficits on inflation for countries with varying levels of inflation.

In addition, the results reveal that money supply growth has a positive and significant effect on inflation. This finding lends support to the claim that growth in monetary aggregates leads to inflation. The finding is also consistent with that reported by Paun and Topan (2013) for Romania. The positive sign of the money supply growth coefficient suggests that in a high-inflationary environment no one wants to hold cash, which makes the prices of goods rise. The results also illustrate that economic growth has a negative and significant effect on inflation. The negative impact of economic growth suggests that the expansion of goods and services will match aggregate demand over time, leading to lower inflation.

\section{CONCLUSION AND RECOMMENDATIONS}

This paper investigates whether the deficits-inflation relationship is non-linear from 1999 to 2011 in 51 African economies, which are further grouped as high-inflation/low-income countries and moderateinflation/middle-income, using fixed-effects and GMM estimators. The results indicate that the deficitsinflation relationship is non-linear, and that the effect of deficits on inflation varies across different income groups with disparate levels of inflation.

Although the results of this research cannot be used as the basis for generalization, the findings of this study highlight the importance of grouping countries according to their levels of inflation and/or income, rather than treating them as a homogeneous entity when examining the deficits-inflation nexus, particularly for the African continent. Although different effects from fiscal deficits have been established across different groups of countries, reducing deficits can check excessive increases in inflation in Africa over time.

\section{REFERENCES}

Abu, N. and Karim, M. Z. A. 2012. Inflationary effects of fiscal deficits in developing countries: Empirical evidence from Africa. A paper presented at the Universiti Putra Malaysia National Research \& Innovation Conference for Graduate Students in Social Sciences, December, 276-286.

Ahking, F. W. and Miller, S. M. 1985. The relationship between government deficits, money growth and inflation. Journal of Macroeconomics 7: 447-467.

Alesina, A. and Drazen, A. 1991. Why are stabilizations delayed?. American Economic Review 81 (5): 1170-1188.

Amato, J. D. and Gerlach, S. 2002. Inflation targeting in emerging market and transition economies: Lessons after a decade. European Economic Review 46: 781-790.

Anoruo, E. C. 2003. An empirical investigation into the budget deficit-inflation nexus in South Africa. South African Journal of Economics 71 (2): 146-154.

Arellano, M. and Bond, S. 1991. Some tests of specification for panel data: Monte Carlo evidence and an application to employment equations. Review of Economic Studies 58: 277-297.

Asiedu, E. 2006. Foreign direct investment in Africa: The role of natural resources, market size, government policy, institutions and political instability. World Economy 29 (1): 63-77.

Catao, L. and Terrones, M. E. 2005. Fiscal deficits and inflation. Journal of Monetary Economics 52: 529-554.

Cottarelli, C., Griffiths, M. and Moghadam, R. 1998. The nonmonetary determinants of inflation: A panel data study. IMF Working Paper 23.

Cukierman, A., Edwards, S. and Tabellini, G. 1992. Seigniorage and political instability. American Economic Review 82: 537-555.

De Haan, J. and Zelhorst, D. 1990. The impact of government deficits on money growth in developing countries. Journal of International Money and Finance 9: 455-469.

Edwards, S. and Tabellini, G. 1991. Explaining fiscal policies and inflation in developing countries. Journal of International Money and Finance 10: 16-48.

Fischer, S. 1993. The role of macroeconomic factors in growth. Journal of Monetary Economics 32: 485-512.

Fischer, S., Sahay, R. and Vegh, S. 2002. Modern hyper and high inflations. Journal of Economic Literature $\mathrm{XL}$ : 837-880.

Habibullah, M. S., Cheah, C. and Baharom, A. H. 2011. Budget deficits and inflation in thirteen Asian developing countries. International Journal of Business and Social Science 2 (9): 192-204.

Hamburger, M. J. and Zwick, B. 1981. Deficit, money and inflation. Journal of Monetary Economics 7: 141-150.

Jacobs, D., Schoeman, N. J. and Van Heerden, J. H. 2002. Alternative definitions of the budget deficit and its impact on the sustainability of fiscal policy in South Africa. South African Journal of Economics 70 (3): 251-257. 
Jalil, A., Tariq, R. and Bibi, N. 2014. Fiscal deficit and inflation: New evidences from Pakistan using a bounds testing approach. Economic Modelling 37: 120-126.

Karras, G. 1994. Macroeconomic effects of budget deficits: Further international evidence. Journal of International Money and Finance 13: 190-210.

King, R. G. and Plosser, C. I. 1985. Money, deficits and inflation. Carnegie-Rochester Conference Series on Public Policy 22: 147-96.

Larsson, R, Lyhagen, J. and Löthgren, M. 2001. Likelihoodbased cointegration tests in heterogeneous panels. Econometrics Journal 4: 109-142.

Lin, H-Y. and Chu, H-P. 2013. Are fiscal deficits inflationary?. Journal of International Money and Finance 32: 214-233.

Marco, B. and Butters, R. A. 2010. What is the relationship between large deficits and inflation in industrialized countries?. Federal Reserve Bank of Chicago Economic Perspectives Q3: 83-100.

McMillin, W. D. and Beard, T. R. (1982). Deficits, money and inflation. Journal of Monetary Economics 10: 273-277.

Metin, K. 1998. The relationship between inflation and the budget deficits in Turkey. Journal of Business and Economic Statistics 16 (4): 412-422.

Paun, C. and Topan, V. 2013. The monetary causes of inflation in Romania. Romania Journal of Economic Forecasting 1: 5-23.

Pedroni, P. 1995. Panel cointegration: Asymptotic and finite sample properties of pooled time series tests with an application to the PPP hypothesis. Indian University Working Papers on Economics.

Pedroni P. 1999. Critical values for cointegration tests in heterogeneous panels with multiple regressors. Oxford
Bulletin of Economics and Statistics (Special Issue) 03059049: 653-670.

Perkarski, S. 2008. Budgets deficits and inflation feedback. CORE Discussion Paper 54.

Rother, P. C. 2004. Fiscal policy and inflation volatility. European Central Bank Working Paper Series 317.

Sahan, F. and Bektasoglu, Y. 2010. Panel cointegration analysis of budget deficit and inflation for EU countries and Turkey. A Paper presented at the Izmir University of Economics 6th Internatioanl Student Conference, Izmir, Turkey.

Sargent, T. and Wallace, N. 1981. Some unpleasant monetarist arithmetic. Federal Reserve Bank of Minneapolis Quarterly Review 1-17.

Shahin, W. N. 1992. Money supply and deficit financing in economic development. Westport Connecticut, Greenwood.

Sill, K. 2005. Do budget deficits cause inflation?. Business Review Q3: 26-33.

Solomon, M. and de Wet, W. A. 2004. The effect of a budget deficit on inflation: The case of Tanzania. South African Journal of Economic and Management Sciences 7 (1): 100-116.

Sutherland, A. 1997. Fiscal crises and aggregate demand: Can high public debt reverse the effects of fiscal policy?. Journal of Public Economics 65: 147-162.

Tan, E. C. 2006. Fiscal deficits, inflation, and economic growth in a successful open developing economy. Review of Applied Economics 12 (1): 129-139.

Tekin-Koru, A. and Özmen, E. 2003. Budget deficits, money growth and inflation: The Turkish evidence. Applied Economics 35 (5): 591-596. 